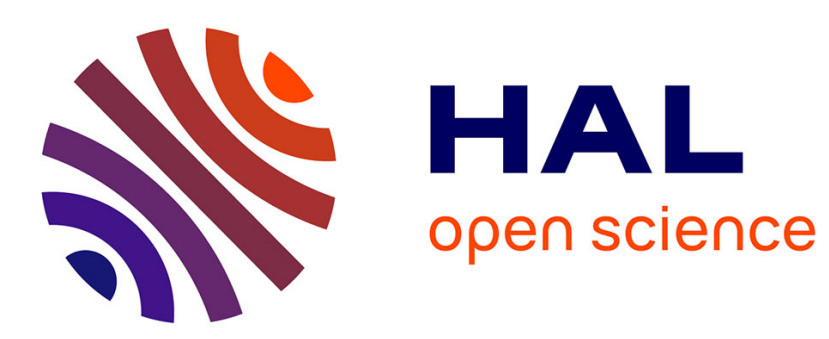

\title{
DISTRIBUTION OF Al IN Nd-Fe-Al-B PERMANENT MAGNETS
}

\author{
A. Hauet, D. Lemarchand, B. Labulle, J. Teillet, P. Vigier
}

\section{To cite this version:}

A. Hauet, D. Lemarchand, B. Labulle, J. Teillet, P. Vigier. DISTRIBUTION OF Al IN Nd-FeAl-B PERMANENT MAGNETS. Journal de Physique Colloques, 1988, 49 (C8), pp.C8-607-C8-608. 10.1051/jphyscol:19888277 . jpa-00228447

\section{HAL Id: jpa-00228447 https://hal.science/jpa-00228447}

Submitted on 1 Jan 1988

HAL is a multi-disciplinary open access archive for the deposit and dissemination of scientific research documents, whether they are published or not. The documents may come from teaching and research institutions in France or abroad, or from public or private research centers.
L'archive ouverte pluridisciplinaire HAL, est destinée au dépôt et à la diffusion de documents scientifiques de niveau recherche, publiés ou non, émanant des établissements d'enseignement et de recherche français ou étrangers, des laboratoires publics ou privés. 


\title{
DISTRIBUTION OF Al IN Nd-Fe-Al-B PERMANENT MAGNETS
}

\author{
A. Hauet $\left({ }^{1}\right)$, D. Lemarchand $\left({ }^{1}\right)$, B. Labulle $\left({ }^{1}\right)$, J. Teillet $\left({ }^{2}\right)$ and P. Vigier $\left({ }^{1}\right)$ \\ (1) UA 808, Faculté des Sciences de Rouen, BP 118, 76134 Mont-Saint-Aignan Cedex, France \\ (2) LPCM, INSA, BP 8, 76131 Mont-Saint-Aignan Cedex, France
}

\begin{abstract}
Fe}$ Mössbauer spectroscopy and electron microprobe analysis are used to determine the Al-distribution in the Nd-Fe-Al-B alloys; Mössbauer spectroscopy gives the $\mathrm{Al}$ distribution between the $\mathrm{J}_{2}$ and $\mathrm{K}_{2}$ sites of $\mathrm{Nd}_{2} \mathrm{Fe}_{14} \mathrm{~B}$-likephase; microprobe analysis gives the composition of both matrix and minor phases and their evolution with sintering.
\end{abstract}

Substitution of $\mathrm{Al}$ for $\mathrm{Fe}$ in the $\mathrm{Nd}-\mathrm{Fe}-\mathrm{B}$ permanent magnets increases $H_{\mathrm{c}}$ and decreases $B_{\mathrm{r}}$ and $T_{\mathrm{c}}$ $[1,2]$. A ${ }^{57} \mathrm{Fe}$ Mössbauer study and a microprobe investigation allowed us to determine the distribution of $\mathrm{Al}$ atoms in as-cast and sintered alloys of nominal weight composition

$\mathrm{Nd}_{33.7}\left(\mathrm{Fe}_{1-y} \mathrm{Al}_{y}\right)_{65.15} \mathrm{~B}_{1.15}$ and

$\mathrm{Nd}_{35.8}\left(\mathrm{Fe}_{1-y} \mathrm{Al}_{y}\right)_{63.1} \mathrm{~B}_{1.1}$ for $y=0.007$;

$y=0.017 ; y=0.027$ which correspond to a nominal atomic ratio $(\mathrm{Al} / \mathrm{Al}+\mathrm{Fe})$ of $0.015 ; 0.035 ; 0.055$.

In addition to the magnetic $\mathrm{Nd}_{2} \mathrm{Fe}_{14} \mathrm{~B}$ type phase Mössbauer spectra show the paramagnetic phase $\mathrm{Nd}_{1.1} \mathrm{Fe}_{4} \mathrm{~B}_{4}$ (weight $6 \%$ ); no other phase was detected except iron traces in as-cast alloys; high and low Nd alloys show similar spectra.

A low substitution of $\mathrm{Al}$ ( 1 to 3 atoms per unit cell) in the $\mathrm{Nd}_{2} \mathrm{Fe}_{14 \mathrm{~B}}$-like phase dramatically changes the Mössbauer spectra: decreasing of mean magnetic fields at iron sites and asymmetric line-broadening typical of a hyperfine field distribution (Fig. 1); this seems to give evidence that substitution takes place mainly in the most magnetic sites (i.e. those with the higher number of nearest-neighbour-iron atoms), to say $\mathrm{J}_{2}$ and $\mathrm{K}_{2}$, which are also the largest sites [3, 4]. Assuming this preferential occupation the spectra are fitted with a near-neighbour-model, which takes into account the decreasing of hyperfine field $\Delta H_{i}$ at avery site $i$ (due to

Table I. - Distribution of $n \mathrm{Al}$ atoms between $J_{2}$ and $K_{2}$ per unit cell in $\mathrm{Nd}_{2}\left(\mathrm{Fe}_{1-x} \mathrm{Al}_{x}\right)_{14} \mathrm{~B}$. $\left(n_{\mathrm{e}}\right.$ : nominal concentration, $n_{m}$ : microprobe analysis, $n:$ mössbauer fits).

\begin{tabular}{|c|c|c|c|c|c|}
\hline$x$ & $n_{\mathrm{e}}$ & $n_{\mathrm{m}}$ & $n$ & $\begin{array}{c}z \\
\mathrm{~J}_{2}\end{array}$ & $\begin{array}{c}n-z \\
\mathrm{~K}_{2}\end{array}$ \\
\hline 0.015 & 0.84 & 1.0 & 0.85 & 0.85 & 0 \\
\hline 0.035 & 1.96 & 1.9 & 2.0 & 1.1 & 0.9 \\
\hline 0.055 & 3.08 & 3.1 & 3.0 & 1.5 & 1.5 \\
\hline & & \pm 0.2 & \pm 0.1 & \pm 0.1 & \\
\hline
\end{tabular}

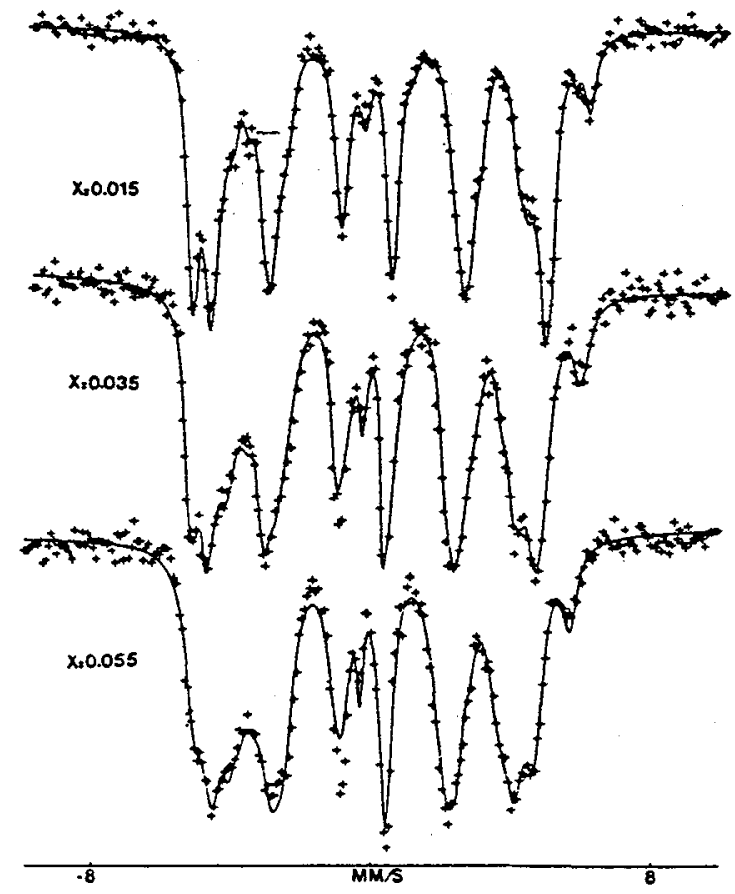

Fig. 1. $-{ }^{57} \mathrm{Fe}$ Mössbauer spectra of $\mathrm{Nd}_{2}\left(\mathrm{Fe}_{1-x} \mathrm{Al}_{x}\right)_{14} \mathrm{~B}$ at room temperature.

an $\mathrm{Al}$ atom near-neighbour of a $\mathrm{Fe}$ atom) and this leads to the determination in the $\mathrm{Nd}_{2} \mathrm{Fe}_{14} \mathrm{~B}$ - like phase, of the $\mathrm{Al}$ concentration, the $\mathrm{Al}$ distribution between the sites (Tab. I) and the iron hyperfine fields.

In all the samples, we found (in the magnetic phase) the Al nominal atomic concentration.

Fits show that Al substitution occurs first in the $\mathrm{J}_{2}$ sites up to a concentration corresponding to one substituted atom per cell. Further Al substitution occurs also in the $K_{2}$ site up to an equipartition between the two sites for $n=3(x=0.055)$.

Hyperfine fields decrease with $n$ but $\Delta H_{i}$ remains fairly constant (about $20 \mathrm{kOe}$ ) except for $J_{2}$ sites where it is about $10 \mathrm{kOe}$ (probably due to a greater distance). 
Electron microprobe analysis allowed us to study both the matrix and the minor phases.

In the matrix phase, we found a homogeneous $\mathrm{Al}$ distribution, with composition close to that determined with Mössbauer spectroscopy (Tab. I).

The B-rich $\mathrm{Nd}_{1.1} \mathrm{Fe}_{4} \mathrm{~B}_{4}$ phase, however is observed to have a near-zero $\mathrm{Al}$ concentration. In the Nd-rich phase, the Al distribution is not homogeneous and generally very low compared with the distribution in the matrix phase (Figs. 2a and 2b).
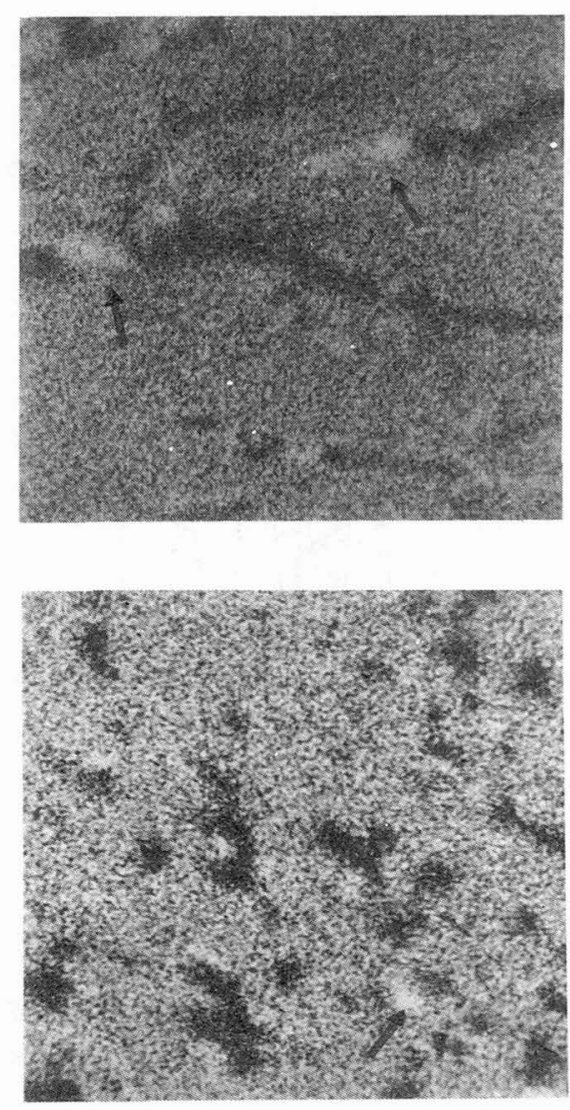

Fig. 2. - Electron microprobe micrographs for AlK $\alpha$ : a) as. cast ingot; b) sintered magnet $(100 \times 100 \mu \mathrm{m})$. The arrows indicate the Al-rich phase.

Moreover, in the as-cast samples, we detected $\mathrm{Al}$. concentrations up to $5 \%$ weight together with $\mathrm{Nd}$ and $\mathrm{Fe}$, suggesting the existence of an Al- rich phase [5] which is located in the Nd-rich intergranular phase in the ingots or in the triple junction phase in the sintered samples. The latter seems to disappear partially during sintering.

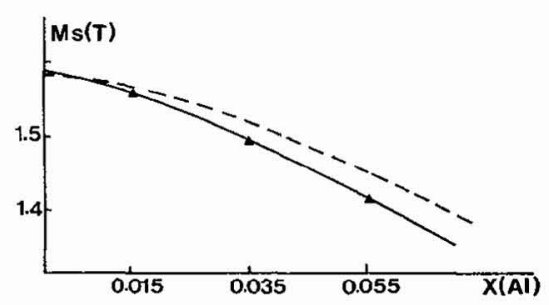

Fig. 3. - Calculated and experimental saturation magnetization [7] (dashed line) versus Al-content.

At last, the saturation magnetization versus $\mathrm{Al}$ concentration was calculated assuming proportionality of the mean hyperfine field (given by Mössbauer spectroscopy) with the mean magnetic moment at iron sites [6]. A good agreement is observed wih the experimental values (Fig. 3).

[1] Grössinger, R., Keresztes, A., Harada, H. and Shougong, Z., 9th Int. workshop on rareearth magnets and their applications (Bad Soden) 31 Aug.-2 sept. 1987.

[2] Abache, C., Oesterreicher, H., J. Appl. Phys. 60 (1986) 1114.

[3] Ying-Chang, Tharp, D. E., Long, G. J., Pringle, O. A. and James, W. J., J. Appl. Phys. 61 (1987) 4343.

[4] Gao, Xiaomei, Qian, Xiangrong and Zhu, Jianqing, 5th Int. Symp. on magnetic aisotropy and coercitivity in rare earth transition metal alloys (Bad Soden) 3 sept. 1987.

[5] Schrey, P., IEE Trans. Magn. Magn. 22 (1986) 913.

[6] Gubbens, P. C. M., Van Apeldoorn, J. H. F., Van Der Kraan, A. and Buschow, K. H. J., J. Phys. F 4 (1974) 921.

[7] Rodewald, W., 9th Int. Workshop on rare earth magnets and their applications (Bad Soden) 31 Aug., 2 sept. 1987. 